\title{
IAMJ
}

INTERNATIONAL

AYURVEDIC

MEDICAL JOURNAL

Research Article

ISSN: $2320-5091$

Impact Factor: 6.719

\section{COMPARATIVE CLINICAL EVALUATION ON THE EFFECT OF GUDUCHI VATI AND YASTIMADHU VATI ON MEDHA (ACADEMIC PERFORMANCE) IN SCHOOL GOING CHILDREN}

\author{
Anjali Varghese ${ }^{1}$, Anil Kumar Rai ${ }^{2}$, Ravi Prasad Hegde ${ }^{3}$ \\ ${ }^{1}$ PG Scholar, ${ }^{2}$ Professor and HOD, ${ }^{3}$ Associate Professor \\ Dept of P.G. Studies in Manovijnana Evam Manasa Roga, AAMC, Moodbidri, D.K., Karnataka, India
}

Corresponding Author: dranjalivarghese@gmail.com

https://doi.org/10.46607/iamj1309102021

(Published Online: October 2021)

Open Access

C International Ayurvedic Medical Journal, India 2021

Article Received: 01/10//2021 - Peer Reviewed: 09/10/2021 - Accepted for Publication: 11/10/2021

\section{Check for updates}

\begin{abstract}
Medha is a concept in Ayurveda where man has always failed to arrive at a definite conclusion. As per the ayurvedic classics, Medha is the retention power of an individual or is the unobstructed and uninterrupted perception and retention of knowledge in all the aspects of an object ${ }^{[1]}$ Academic Performance of an individual is an outcome of his mental and physical potential. Recent studies show that the intellectual abilities of students have a positive association with their scholastic achievement. ${ }^{[2]}$ Acharya Charaka has mentioned 4 individual drugs under Charakoktha Medhya Rasayanas for their action on Medha ${ }^{[3]}$ and Guduchi Swarasa and Yastimadhu Ksheerapaka are mentioned among them. In this study, an attempt was made to evaluate the Medhya effect of Guduchi Vati and Yastimadhu Vati. The study was a comparative clinical study with a total subject of 40, where 20 patients were administered with Guduchi Vati and the other 20 with Yastimadhu Vati. The study showed a statistically significant result where the Guduchi Vati is having similar action to that of Yastimadhu Vati on Medha (Academic Performance) in School going children.
\end{abstract}

Keywords: Guduchi Vati, Yastimadhu Vati, Medha, Academic Performance 


\section{INTRODUCTION}

Medha is a concept in Ayurveda where man has always failed to arrive at a definite conclusion. As per the ayurvedic classics, Medha is the retention power of an individual or is the unobstructed and uninterrupted perception and retention of knowledge in all the aspects of an object.

The Academic Performance of an individual is an outcome of his mental and physical potential; besides the experience, he has gained in the process of exploration and learning. If we consider a group of students, it is normal that a few students are found to be high achievers on the one hand, and a few are underachievers on the other, while a sizable number of students usually appear as moderate achievers. Does the question arise why such a difference in achievement appears when the schools provide uniform instructional and environmental faculties? Various investigations and studies have explored numerous factors which are found responsible for academic success and failure. The most important factor among them is intellectual ability. Recent studies show that the intellectual abilities of students have a positive association with their scholastic achievement. ${ }^{[4]}$

Understanding the intellectual process is a complex phenomenon. But in a broad sense, we can describe intelligence as an aggregate or global capacity of an individual to act purposefully to think rationally and to deal effectively with his environment. ${ }^{[5]}$ A decrease in Intelligence level may limit an individual in areas such as learning, reasoning, communication and self-help skill.

Mind and intellect are among the phenomena on which man always failed to reach a definite conclusion. $\mathrm{Hu}-$ man being has conquered the peaks in all aspects of life because of unlimited thoughts as well as ambitions. The pace of life got increased and human beings have become accustomed to a competitive world. The competitive spirit is being injected by society even into the brain of children. Once a child is born the parents start designing his or her future to build him up as a doctor or engineer. Many parents are ready to purchase supplements for their children to prepare them for the exams. The scientists, as well as businessmen, have come forward to take the "enhance memory" or as "IQ. Booster" to take advantage of this situation and the idea is utilized by multinational companies for monetary benefits.

In Ayurveda, a group of drugs mentioned as Medhya Rasayanas are established in boosting brain function and making the brain healthier also. ${ }^{[6]}$ Medhya Rasayanas (Herbal nootropic drugs) are a group of medicinal plants described by Acharya Charaka which helps in improving memory and intellect by its Prabhava (specific action). ${ }^{[7]}$ Acharya Charaka has mentioned 4 individual drugs under Charakoktha Medhya Rasayanas [8] Guduchi Swarasa and Yastimadhu Ksheerapaka are mentioned among them. Medhya drugs activate brain function by improving the function of Agni and better circulation of Rasa by cleaning the microchannel. ${ }^{[9]}$ The main function of Medhya Rasayanas is to improve the power of grasping, power of retention, power of discrimination and power of recollection. In this study, an attempt was made to evaluate the Medhya effect of Guduchi and Yastimadhu which was modified into Vati form for the convenience of the subjects.

\section{MATERIALS AND METHODS}

Study Design: Randomised comparative clinical study

Sample Size Estimation: As per the incidence of the condition, the sample size estimation was done and implemented for the clinical study. In the present study, 40 patients fulfilling the diagnostic and inclusion criteria were registered. They were assigned randomly into two equal groups A and B for the study through the lottery method.

Sample Size: 40 subjects were selected and divided into two groups of 20 each.

Duration of Study: 45 days

Method of Sampling: Simple Random Sampling Diagnostic Criteria: Diagnosis will be made based on Academic Performance using School progress records-cut off marks below 50\%.

Inclusion Criteria: Students of either gender, aged between 10-16 years regularly attend classes with academic marks below $50 \%$ 


\section{Exclusion Criteria:}

Students suffering from any psychiatric illness and students suffering from any systemic illness.

\section{Specification of the nature of the Study:}

1. Diagnostic Phase

2. Interventional Phase

3. Assessment Phase

Diagnostic Phase - it was done based on diagnostic, inclusion and exclusion criteria.

Interventional Phase - the study intervened by treatment with Guduchi Vati and Yastimadhu Vati.

Group A: Guduchi Choorna was taken in Q.S part and was pounded to a fine powder and triturated with freshly collected Guduchi Swarasa to get Samyak Bhavita Lakshana. After the attainment of Samyak Bhavita Lakshana, the mixture was dried. This procedure was done for 3 days. The collected dry powder was made into Vati form.

Group B: Yastimadhu Choorna was taken in Q.S part and was pounded to a fine powder and triturated with freshly collected Ksheera to get Samyak Bhavita Lakshana. After the attainment of Samyak Bhavita Lakshana, the mixture was dried. This procedure was done for 3 days. The collected dry powder was made into Vati form.
Duration of Study: 30 days

Follow up: The patient was observed before the treatment and on the $30^{\text {th }}$ day after the treatment and the $45^{\text {th }}$ day.

Total study duration: 45 days

Assessment Phase - Assessment was done based on subjective and objective parameters.

Subjective Parameters

1) Reduced concentration (0-3)

2) Poor attention (0-3)

3) Poor grasping power (0-3)

4) Poor retention (0-3)

5) Lethargy (0-3)

Scoring: 0 -Absent, 1 - Mild, 2 - Moderate, 3 - Severe. Objective Parameters:

1) Academic Performance in School

2) Malins Intelligence Scale

And the further analysis was done by Statistical tests, within-group - paired t-test and Wilcoxon signed-rank test, between Group - unpaired t-test and Mann Whitney u test was applied.

\section{Assessment of Overall effect of the treatment:}

The overall effect of the intervention was estimated in the following 4 categories.

Table 1: Overall Effect

\begin{tabular}{|l|l|}
\hline 1. Marked improvement & $76-99 \%$ \\
\hline 2. Moderate improvement & $51-75 \%$ \\
\hline 3. Mild improvement & $26-50 \%$ \\
\hline 4. No improvement & $<25 \%$ \\
\hline
\end{tabular}

\section{OBSERVATION AND RESULT}

\section{Effect on Academic Performance}

Table 2: Effect on Academic Performance in Group A

\begin{tabular}{|l|l|l|l|l|l|l|l|}
\hline AP & MEAN BT & $\begin{array}{l}\text { MEAN } \\
\text { AT }\end{array}$ & $\begin{array}{l}\text { MEAN } \\
\text { FU }\end{array}$ & \% IMP & SEM & t value & p-value \\
\hline KANNADA & 44.95 & 50.15 & 49.25 & $11.56 \%$ & 1.307 & 3.978 & $<0.001$ \\
\hline ENGLISH & 43.90 & 49.30 & 49.75 & $12.3 \%$ & 1.139 & 4.742 & $<0.001$ \\
\hline HINDI & 43.65 & 47.80 & 49.75 & $9.50 \%$ & 0.737 & 5.629 & $<0.001$ \\
\hline SOCIAL & 43.35 & 48.00 & 48.70 & $10.72 \%$ & 1.032 & 4.507 & $<0.001$ \\
\hline SCIENCE & 43.30 & 50.40 & 51.05 & $16.39 \%$ & 1.526 & 4.850 & $<0.001$ \\
\hline MATHS & 42.45 & 49.15 & 50.05 & $15.78 \%$ & 1.29 & 5.186 & $<0.001$ \\
\hline
\end{tabular}


Table 3: Effect of Academic Performance in Group B

\begin{tabular}{|l|l|l|l|l|l|l|l|}
\hline AP & $\begin{array}{l}\text { MEAN } \\
\text { BT }\end{array}$ & $\begin{array}{l}\text { MEAN } \\
\text { AT }\end{array}$ & $\begin{array}{l}\text { MEAN } \\
\text { FU }\end{array}$ & \% IMP & SEM & t value & p-value \\
\hline KANNADA & 46.40 & 48.90 & 48.30 & $5.38 \%$ & 0.478 & 5.225 & $<0.001$ \\
\hline ENGLISH & 45.05 & 47.00 & 46.95 & $4.32 \%$ & 0.407 & 4.791 & $<0.001$ \\
\hline HINDI & 43.50 & 45.60 & 45.55 & $4.82 \%$ & 0.422 & 4.972 & $<0.001$ \\
\hline SOCIAL & 45.35 & 47.75 & 47.10 & $5.29 \%$ & 0.510 & 4.707 & $<0.001$ \\
\hline SCIENCE & 44.85 & 48.00 & 48.15 & $7.02 \%$ & 0.509 & 6.185 & $<0.001$ \\
\hline MATHS & 42.75 & 46.30 & 46.80 & $8.30 \%$ & 0.484 & 7.337 & $<0.001$ \\
\hline
\end{tabular}

Table 4: Effect of Academic Performance between Group A and B

\begin{tabular}{|c|c|c|c|c|c|c|c|c|c|}
\hline \multirow[t]{2}{*}{$\mathbf{A P}$} & \multicolumn{2}{|l|}{ MEAN } & \multirow{2}{*}{$\begin{array}{l}\text { MEAN } \\
\text { DIFFERENCE } \\
(\mathrm{A}-\mathrm{B})\end{array}$} & \multicolumn{2}{|c|}{ SD } & \multicolumn{2}{|c|}{ SE } & \multirow[t]{2}{*}{ t value } & \multirow[t]{2}{*}{ p-value } \\
\hline & A & B & & A & B & A & B & & \\
\hline KANNADA & 50.150 & 48.900 & 1.250 & 4.771 & 4.723 & 1.067 & 1.056 & 0.833 & 0.410 \\
\hline ENGLISH & 49.300 & 47.000 & 2.300 & 6.760 & 5.058 & 1.512 & 1.131 & 1.218 & 0.231 \\
\hline HINDI & 47.800 & 45.600 & 2.200 & 6.254 & 5.030 & 1.398 & 1.125 & 1.226 & 0.228 \\
\hline SOCIAL & 48.00 & 47.750 & 0.250 & 8.092 & 5.618 & 1.809 & 1.256 & 0.113 & 0.910 \\
\hline SCIENCE & 50.400 & 48.000 & 2.400 & 6.969 & 6.078 & 1.558 & 1.359 & 1.161 & 0.253 \\
\hline MATHS & 49.150 & 46.300 & 2.850 & 9.098 & 5.723 & 2.034 & 1.280 & 1.186 & 0.243 \\
\hline
\end{tabular}

\section{Effect on Intelligence Quotient}

Table 5: Effect on Verbal and Performance IQ in group A

\begin{tabular}{|l|l|l|l|l|l|}
\hline IQ & MEAN & SD & SE & value & p-value \\
\hline Verbal BT & 87.300 & 5.283 & 1.181 & 595 & 0.018 \\
\hline Verbal AT & 88.050 & 4.785 & 1.070 & & \\
\hline Per BT & 88.100 & 4.471 & 1.000 & 290 & 0.004 \\
\hline Per AT & 88.850 & 4.184 & 0.935 & & \\
\hline
\end{tabular}

Table 6: Effect on Total Intelligence Quotient within the Group A

\begin{tabular}{|l|l|l|l|l|l|l|l|}
\hline PARAMETER & Mean BT & Mean AT & Mean FU & \% IMP & SEM & t - value & p-value \\
\hline IQ & 87.70 & 88.45 & 88.80 & $0.855 \%$ & 0.204 & 3.684 & $<0.05$ \\
\hline
\end{tabular}

Table 7: Effect on Verbal and Performance IQ in group B

\begin{tabular}{|l|l|l|l|l|l|}
\hline IQ & MEAN & SD & SE & t & p \\
\hline Verbal BT & 86.850 & 3.453 & 0.772 & 2.651 & 0.016 \\
\hline Verbal AT & 87.300 & 3.246 & 0.726 & & \\
\hline Per BT & 87.100 & 2.989 & 0.668 & 1.926 & 0.069 \\
\hline Per AT & 87.450 & 3.052 & 0.682 & & \\
\hline
\end{tabular}


Table 8: Effect on Total Intelligence Quotient within the Group B

\begin{tabular}{|l|l|l|l|l|l|l|l|}
\hline PARAMETER & Mean BT & Mean AT & Mean FU & $\%$ IMP & SEM & $\mathrm{t}$ - value & p-value \\
\hline IQ & 87.00 & 87.35 & 87.10 & $0.04 \%$ & 0.109 & 3.199 & $<0.05$ \\
\hline
\end{tabular}

Table 9: Comparison of treatment on Total IQ Between the group A \& B

\begin{tabular}{|c|c|c|c|c|c|c|c|c|c|}
\hline \multirow[t]{2}{*}{ PARAMETER } & \multicolumn{2}{|c|}{ MEAN } & \multirow{2}{*}{$\begin{array}{l}\text { MEAN } \\
\text { DIFFERENCE } \\
(\mathrm{A}-\mathrm{B})\end{array}$} & \multicolumn{2}{|l|}{ SD } & \multicolumn{2}{|l|}{ SE } & \multirow[t]{2}{*}{$t$ value } & \multirow{2}{*}{$\begin{array}{l}p- \\
\text { value }\end{array}$} \\
\hline & A & B & & A & B & A & B & & \\
\hline IQ & 88.450 & 87.350 & 1.100 & 3.316 & 2.739 & 0.742 & 0.612 & 1.144 & 0.260 \\
\hline
\end{tabular}

Table 10: Comparison of treatment on Verbal and Performance IQ Between the groups A \& B

\begin{tabular}{|l|l|l|l|l|l|}
\hline IQ & MEAN & SD & SE & t value & p-value \\
\hline VERBAL & 88.050 & 4.785 & 1.070 & 0.580 & 0.565 \\
\hline PER & 87.300 & 3.246 & 0.726 & & \\
\hline
\end{tabular}

\section{Effect on Intelligence Quotient}

Table 11: Effect on Clinical Symptoms in Group A

\begin{tabular}{|l|l|l|l|l|l|l|}
\hline Clinical Symptoms & Mean BT & Mean AT & Mean FU & \% IMP & wsrt - value & p-value \\
\hline Reduced concentration & 2.45 & 1.00 & 1.80 & $59.18 \%$ & 3.923 & $<0.001$ \\
\hline Poor Attention & 2.20 & 1.10 & 1.85 & $50 \%$ & 3.824 & $<0.001$ \\
\hline Poor Grasping Power & 2.70 & 1.35 & 1.75 & $50 \%$ & 3.835 & $<0.001$ \\
\hline Poor Retention & 2.75 & 0.90 & 1.55 & $67.27 \%$ & 3.976 & $<0.001$ \\
\hline Lethargy & 1.80 & 1.05 & 0.95 & $41.66 \%$ & 3.873 & $<0.001$ \\
\hline
\end{tabular}

Table 12: Effect on Clinical Symptoms within the Group B

\begin{tabular}{|l|l|l|l|l|l|l|}
\hline Clinical Symptoms & Mean BT & Mean AT & Mean FU & \% IMP & wsrt - value & p-value \\
\hline Reduced concentration & 2.40 & 1.65 & 1.70 & $31.25 \%$ & 3.638 & $<0.001$ \\
\hline Poor Attention & 2.55 & 1.55 & 1.95 & $39.21 \%$ & 3.879 & $<0.001$ \\
\hline Poor Grasping Power & 2.55 & 1.40 & 1.45 & 45.09 & 3.758 & $<0.001$ \\
\hline Poor Retention & 2.45 & 1.60 & 1.55 & $34.69 \%$ & 3.9 & $<0.001$ \\
\hline Lethargy & 2.45 & 1.55 & 1.65 & $36.7 \%$ & 3.662 & $<0.001$ \\
\hline
\end{tabular}

Table 13: Comparison of treatment on Clinical Symptoms between the group A \& B

\begin{tabular}{|l|l|l|l|l|l|}
\hline SYMPTOMS & MEAN & SD & \multicolumn{4}{l|}{ Mann - Whitney u Test } \\
\cline { 4 - 6 } & & & U value & Z score & P-value \\
\hline Reduced Concentration (BT - AT) & 1.10 & 0.709 & 96 & 3.158 & $<0.05$ \\
\hline Poor Attention (BT - AT) & 1.05 & 0.639 & 190 & 0.327 & $>0.05$ \\
\hline Poor Grasping Power (BT - AT) & 1.45 & 0.742 & 178.5 & 0.646 & $>0.05$ \\
\hline Poor Retention (BT - AT) & 1.35 & 0.834 & 71.500 & 3.888 & $<0.001$ \\
\hline Lethargy (BT - AT) & 0.82 & 0.549 & 167.500 & 1.161 & $>0.05$ \\
\hline
\end{tabular}




\section{Overall Effect of Therapies}

Table 14: Overall effect in Group A

\begin{tabular}{|l|l|l|}
\hline CLASS & GRADING & SUBJECTS \\
\hline$<25 \%$ & No change & 0 \\
\hline $26-50 \%$ & Mild Improvement & 4 \\
\hline $51-75 \%$ & Moderate Improvement & 6 \\
\hline$>75 \%$ & Marked Improvement & 10 \\
\hline
\end{tabular}

Table 15: Overall Effect in Group B

\begin{tabular}{|l|l|l|}
\hline CLASS & GRADING & SUBJECTS \\
\hline$<25 \%$ & No change & 0 \\
\hline $26-50 \%$ & Mild Improvement & 4 \\
\hline $51-75 \%$ & Moderate Improvement & 9 \\
\hline$>75 \%$ & Marked Improvement & 7 \\
\hline
\end{tabular}

\section{DISCUSSION}

A major part of the life of children is spent in school. ${ }^{[10]}$ Children tend to absorb, conceptualize, synthesize, and express in the early years through school activities. School performance is a key mechanism through which adolescence learn about their talents, abilities, competencies, which are an important part of developing career aspirations. ${ }^{[11-12]}$ But success and acceptance in the school setting depend on children's physical, cognitive, social and emotional adjustment.

Attention level is a key contributor to a child's academic performance. Higher academic performance reflects a higher level of attention, while lower performance reflects a lower level of attention. ${ }^{[13]}$ Many studies show that in school children, fatigue can lead to a decline in school performance. ${ }^{[14]}$ Research in psychology has revealed that scores on memory tests are a useful predictor of several cognitive skills even academic performance. ${ }^{[15]}$

As per classical references, both Guduchi and Yastimadhu is said to have Phalashruti of Rasayana "Dheergamayusmritimedha". This concept was proved again with the help of a clinical experiment. ${ }^{[16]}$ Both the drugs have strong antioxidant properties and act as a brain tonic. The results of many studies suggest the nootropic action of both drugs involving cholinergic and GABAergic modulation. ${ }^{[17]}$
The Medhya Karma is considered as Prabhava Jayna because some Medhya Dravya are Sita Virya, Madhura Rasa and Madhura Vipaka e.g., Yastimadhu; and some are Tikta Rasa and Usna Virya e.g., Guduchi. These Medhya Dravya have more Medhya Karma present rather than a Samanya Dravya, so, Medhya Karma is Prabhava Janya. ${ }^{[22]}$ Grahana Shakti (power of acquisition), Dharana shakti (power of retention) and Smriti (power of recollection), all three are included in Medha. Pitta is Ashu and Tikshna, so it is helpful in Vishaya Grahana and Smriti, that's why Medha is included in Prakrit Karma of Pitta. Vata is also necessary for the association of ideas in the process of Smriti. Kapha provides Dhriti (Dharana) and stability that's why Sthirita and Dhriti are included in Prakrit Karma of Kapha. Due to all these reasons, the Usna Virya and Sita Virya Draya should be Medhya. But Usna Virya Dravya for Vishaya Grahana and Smriti rather than Sita Virya for Dharan Shakti. ${ }^{[23]}$

\section{CONCLUSION}

The data reported in this study confirm and authenticate the effect of Guduchi Vati and Yastimadhu Vati on Medha (Academic Performance). Statistical Analysis further proved that both the drugs help in reducing anxiety, stress which results in better academic performance as indicated by better total scores. Both Guduchi Vati and Yastimadhu Vati showed a statistically significant effect on the assessment criteria i.e., 
in subjective and objective parameters. But in comparison between the 2 groups, we were not able to find any significant difference. Thus, there is an equivalent effect of Guduchi Vati and Yastimadhu Vati on Medha (Academic Performance) in school-going children.

\section{REFERENCES}

1. Anna Moreshwar Kunte. Ashtanga Hrudaya of Vagbhata. 7th Ed, Varanasi: Chowkamba Samskrit Adhishtan, 2002; PP:73.

2. Rohde, T. E., \& Thompson, L. A. (2007). Predicting academic achievement with cognitive ability: Intelligence, 35(1), 83-92.

3. Agnivesha Charaka Samhita, English translation by Sharma RK, Dash B. Vol-III, Chikitsa Sthana (13/30.31), Chaukhambha Sanskrit series office, Varanasi. (2010)

4. Rohde, T. E., \& Thompson, L. A. (2007). Predicting academic achievement with cognitive ability: Intelligence, 35(1), 83-92.

5. Wechsler, D (1940), non-intellective factors in general intelligence; psychological Bulletin,37; PP:444-445.

6. Dartigues J. F, Carcaillon L, Helmer C, Lechevallier N, Lafuma A, Khoshnood B; Vasodilators and nootropics as predictors of dementia and mortality in the PAQUID cohort; Journal of the American Geriatrics Society; 2007; 55(3); PP:395-399.

7. Kulkarni R, Girish KJ, Kumar A (2012): Nootropic herbs (Medhya Rasayana) in Ayurveda: An update. Pharmacognition Rev 6: PP:147-153

8. Agnivesha Charaka Samhita, English translation by Sharma RK, Dash B. Vol-III, Chikitsa Sthana (13/30.31), Chaukhambha Sanskrit series office, Varanasi. (2010)

9. Ray S, Ray A. Medhya Rasyaanas in Brain Function and Disease. Medical chemistry 2015:5:505-511.

10. Kaplon and Saddock 's concise textbook of clinical psychiatry. Second reprint 2009: New Delhi; Wolters Kluwer (Ind) Pvt.Ltd. p. 674

11. Gottfredson LS. Circumscription and Compromise: A developmental theory ofoccupational aspirations. Journal of Counselling Psychology Monograph 1981; 28:545-579

12. Lent RW, Brown SD, Hackett G. Toward a unifying social cognitive theory of career and academic interest, choice, and performance. Journal of vocational behaviour 1994; 45:79-122

13. Acharya JT. Charaka Samhita with Ayurvedadipika
Commentary by Chakarpanidatta, editor Acharya YT. Varanasi: Choukhambha Orientalia; 2011; PP:109.

14. Breslau J: Poor attention predicts lower high school test scores; Medical journal paediatrics; University of California; 2009; 44(3); PP: 210-214.

15. Fukuda S, Yamano E, Joudoi T, et al. effort-reward imbalance for learning is associated with fatigue in school children. Behavioural Med 2010; 36(2); 5362.

16. Dr Atul Shankar Sarokte et al; effects of Medhya Rasayana in the improvement of short-term memory among school-going children; ayu, 2013,34(4), 383389.

17. Agnivesha Charaka Samhita; with Ayurveda Deepika commentary of chakrapani; edited by Vaidya jadavaji trikaji Acarya; published by chaukambha prakashan, Varanasi; reprint:2011; Chikitsa sthana 1/7-8; PP: 377

18. Dr Almas taranum et al; a clinical study on the efficacy of guduchi on IQ in school going children; international ayurvedic medical journal; ISSN 23205091

19. Agnivesha, Charaka, Charaka Samhita, Chikitsa sthana, Rasayana Adhyaya 1, Pada 3/30, edited by Acharya Yadavaji Trikamaji, Chaukhamba Prakashan, Varanasi, 2011; PP:385

20. Pandey G. Dravyaguna Vijnana Part II. Varanasi: Chaukambha Krishnadas Acadamy; 2004. p. 462-8

21. MM Agnivesh, Charak Samhita. part I, Sutra sthana Trisothiya adhyaya 18/51, Edited by Shastri SN, Chaukhambha Bharti Academy, Varanasi.2011; PP: 385

22. Vaya J, Belinky PA, Aviram M. Structural aspects of the inhibitory effect of glabridin on LDL oxidation. Free Rad Biol Med. 1998; 24:1419-29.

23. Rathee P, Chaudhary H, Rathee S, Rathee D. Natural memory boosters. Phcog Rev. 2008; 2:249-56

\section{Source of Support: Nil Conflict of Interest: None Declared}

How to cite this URL: Anjali Varghese et al: Comparative Clinical Evaluation On The Effect Of Guduchi Vati And Yastimadhu Vati On Medha (Academic Performance) In School Going Children. International Ayurvedic Medical Journal \{online\} 2021 \{cited October 2021\} Available from: http://www.iamj.in/posts/images/upload/2378_2384.pdf 